E-ISSN. 2685-7650

Vol. 2 No. 2 (2020), pp 1-19

DOI: https://doi.org/10.33366/jkn.v2i2.46

\title{
Dampak Work From Home Selama Pandemi Covid-19 terhadap Kondisi Fisiologis dan Perilaku Komunikasi
}

\author{
Dewanto Putra Fajar \\ Program Studi Ilmu Komunikasi, Universitas Brawijaya \\ Email: dewanto.pf@ub.ac.id
}

\begin{abstract}
The Covid-19 pandemic period brought various major changes to human social life around the world. WFH (working from home) activities have become a new lifestyle for the community, requiring all work activities that were previously done outside the home to be done inside the home. Such a situation creates social shock, which has the potential to cause psychological, physiological, and communication problems. This article attempts to investigate the physiological changes in humans during the WFH period, with indicators of blood pressure (comparison between systole and diastole) and pulse (pulse), to get an idea of the impact of WFH on these indicators. Measurements were carried out for 14 days with measurement periods three times per day (morning, noon, night), using a calibrated digital sfigmonanometer. In addition, this article uses a participatory research approach, direct participant observation, and comparisons of physiological data under normal conditions and in fasting conditions. The data comparison conducted by the researcher gave results in the form of value variations in physiological patterns during WFH activity. The variation in values in physiological conditions indicates that WFH activity indicates that there is a possibility of increased stress in humans, which in turn affects human communication behavior with the surrounding environment.
\end{abstract}

Keywords: Covid-19, Work from home, Communication behavior, Physiology, Communibiology

\begin{abstract}
Abstrak: Masa pandemik Covid-19 membawa beragam perubahan besar terhadap kehidupan sosial manusia di seluruh dunia. Aktivitas WFH (working from home) menjadi gaya hidup baru masyarakat, yang menuntut semua aktivitas pekerjaan yang sebelumnya dikerjakan di luar rumah, berubah menjadi dikerjakan di dalam rumah. Keadaan seperti itu memunculkan keterkejutan sosial (social shock), sehingga berpotensi memunculkan permasalahan psikologis, fisiologis, dan komunikasi. Artikel ini berusaha menyelidiki perubahan-perubahan fisiologis manusia selama masa WFH, dengan indikator tekanan darah (perbandingan antara sistol dan diastol) dan denyut nadi (pulse), untuk mendapatkan gambaran tentang dampak WFH pada sejumlah indikator tersebut. Pengukuran dilakukan selama 14 hari dengan periode pengurkuran sebanyak tiga kali setiap hari (pagi, siang, malam), menggunakan alat sfigmonanometer digital terkalibrasi. Di samping itu, artikel ini menggunakan pendekatan riset partisipatoris, observasi partisipan langsung, serta komparasi data fisiologis dalam kondisi normal dan dalam kondisi berpuasa. Komparasi data yang dilakukan peneliti memberikan hasil berupa variasi nilai pada pola-pola fisiologis selama berlangsungnya aktivitas WFH. Variasi nilai pada kondisi fisiologis menunjukkan bahwa aktivitas WFH memberikan indikasi bahwa ada kemungkinan peningkatan stress pada manusia, yang pada akhirnya mempengaruhi perilaku komunikasi manusia dengan lingkungan sekitarnya.
\end{abstract}

Kata Kunci: Covid-19, WFH, Perilaku Komunikasi, Fisiologis, Communibiology

\section{Pendahuluan}

Akhir tahun 2019 hingga tahun 2020 menjadi masa penting dalam sejarah umat manusia, karena masa itu merupakan masa pandemik global SARS-CoV-2 atau yang lebih dikenal sebagai virus Corona atau Covid-19. Pandemik global Covid-19 memaksa pemerintah mengeluarkan sejumlah kebijakan yang merevolusi hampir semua kehidupan sosial manusia, mulai dari pembatasan sosial, hingga WFH, yang lebih dikenal sebagai WFH (working from home). 


\section{Jurnal Komunikasi Nusantara}

E-ISSN. 2685-7650

Vol. 2 No. 2 (2020), pp 1-19

DOI: https://doi.org/10.33366/jkn.v2i2.46

Kebijakan-kebijakan tersebut memaksa banyak individu untuk meningalkan kebiasaan lama untuk bekerja dari kantor, menjadi bekerja sepenuhnya dari dalam rumah. Kebijakan WFH memberikan sejumlah dampak besar bagi kehidupan masyarakat, sekaligus perilaku komunikasi mereka. Di satu sisi WFH memberikan kesempatan bagi individu untuk memanfaatkan waktu lebih banyak dengan keluarga, namun di sisi lain WFH memberikan efek samping tertentu yang berpengaruh pada kondisi fisiologis dan biologis individu. Sejumlah efek samping dari WFH bisa sangat beragam mulai dari kebosanan yang meningkat, kemungkinan peningkatan potensi pada ketegangan dan stress, yang pada akhirnya mempengaruhi proses komunikasi.

Lebih jauh, pelaksanaan WFH menuntut banyak individu menggunakan media digital untuk menyelesaikan pekerjaan-pekerjaan kantor secara terus-menerus, dalam rentang waktu relatif lama. Perubahan kebiasaan dan perilaku semacam itu memaksa individu berubah dari kebiasaan dari komunikasi tatap muka secara normal, menjadi komunikasi termediasi internet secara tiba-tiba. Perubahan revolusioner pada cara hidup dan komunikasi seperti itu memunculkan tekanan-tekanan terhadap kondisi personal individu, yang secara langsung memaksa masing-masing individu untuk beradaptasi menghadapi perubahan proses dan perilaku komunikasi seperti itu. Sayangnya tidak semua individu siap dan bisa menghadapi perubahan tersebut. Ketidaksiapan individu menghadapi perubahan besar dalam kehidupan sosial dan proses komunikasi akibat WFH, berpotensi mendorong individu merasakan ketegangan, stress, sebagai cara menyesuaikan diri dengan tekanan lingkungan yang terjadi secara mendadak. Hans Selye (Dougall dan Baum, 2003) menjelaskan bahwa stress, dan ketegangan bisa muncul sebagai kompensasi dari tekanan lingkungan dan proses penyesuaian diri individu menghadapi tekanan lingkungan tersebut. Keadaan demikian kemungkinan terjadi pada mayoritas individu yang berkeja dari rumah selama masa pandemik Covid-19.

Pengamatan lebih dalam tentang dampak WFH terhadap kondisi fisiologis individu di tengah pandemik Covid-19 menjadi penting, karena diharapkan bisa memberikan pengetahuan dan rujukan ilmiah tentang dampak WFH. Pada kenyataannya tidak semua individu bisa menghadapi situasi WFH secara positif, sebagian individu memanfaatkan situasi tersebut dengan sejumlah hal positif - seperti family time yang lebih banyak, waktu ibadah yang lebih baik dan semacamnya, namun sebagian lainnya bisa jadi cenderung terbebani dengan situasi WFH tersebut - seperti kegagalan menyesuaikan waktu bekerja dan istirahat, atau beban pekerjaan yang makin tinggi, hingga kehilangan pekerjaan utama, dan sebagainya. Kondisi demikian diperparah dengan kurangnya informasi dan pengetahuan ilmiah tentang dampak WFH terhadap kondisi individu. Karena itu pemahaman tentang dampak WFH terhadap perubahan kondisi fisiologis individu menjadi penting, sebagai strategi untuk menghadapi dan berdamai dengan kondisi WFH.

Artikel ini berusaha mengamati perubahan-perubahan kondisi fisiologis dalam diri manusia, ketika mengalami keterpaksaan WFH, serta implikasi yang muncul dalam perilaku komunikasi manusia secara khusus, khususnya ketika individu harus dipaksa beradaptasi dalam gaya hidup baru selama WFH. Dengan kata lain, artikel ini hanya memfokuskan pengamatan pada efek samping negatif pada diri individu selama pelaksanaan WFH. Karena itu artikel ini tidak memberikan perhatian pada sejumlah dampak positif yang dirasakan individu selama WFH. Secara asumsional, tekanan lingkungan selama WFH memberikan sejumlah dampak 


\section{Jurnal Komunikasi Nusantara}

\section{E-ISSN. 2685-7650}

Vol. 2 No. 2 (2020), pp 1-19

DOI: https://doi.org/10.33366/jkn.v2i2.46

negatif pada kondisi fisiologis individu. Padahal, perubahan kondisi fisiologis dalam diri individu bisa memunculkan perubahan-perubahan di aspek lainnya, termasuk pada perilaku komunikasi. Tekanan dan perubahan lingkungan dan kebiasaan individu selama masa WFH bisa bervariasi, seperti proses adaptasi individu gaya hidup digital sepenuhnya, munculnya beragam gangguan (noise) dari lingkungan sosial, hingga beban pekerjaan yang semakin menumpuk sepanjang waktu. Bagi sejumlah individu beban pekerjaan selama WFH tidak banyak berpengaruh pada kondisi fisiologis, namun bagi individu lainnya, beban pekerjaan selama masa WFH bisa berdampak pada konfigurasi fisiologis tubuhnya. Hal itu menyebabkan masingmasing individu tingkat toleransi stress yang berbeda sehingga memunculkan tingkat reaksi yang berbeda pula. Karena itu, artikel ini mengamati dan mendeskripsikan fluktuasi kondisi fisiologis individu selama WFH dalam rentang waktu sekitar 14 hari-penjelasan detail lihat di subbab metodologi, yang berpotensi memberikan pengaruh pada kondisi fisiologis dan perilaku komunikasi individu. Secara hakekat, perilaku komunikasi manusia tidak dapat lepas dari ranahranah komunikasi secara umum, serta kajian-kajian komunikasi yang berkembang. Artikel ini tidak hanya mengamati dan menjelaskan perubahan-perubahan kondisi fisiologis individu, tapi juga perubahan perilaku komunikasi individu yang terjadi di ranah kajian komunikasi interpersonal.

Dampak negatif proses adaptasi tubuh manusia menghadapi perubahan lingkungan dicetusakan oleh tiga ilmuwan besar dari rentang masa berbeda dan prespektif berebda, namun topik kajian mereka sama. Walter Cannon merupakan ilmuwan pertama yang berhasil mengidentifikasi perubahan kondisi fisiologis tubuh manusia ketika meghadapi tekanan dari luar. Ia menjelaskan bahwa tubuh manusia secara umum berada pada kondisi homestasis (keseimbangan), yang dikendalikan sistem saraf tepi, sehingga semua perubahan kondisi fisiologis individu ketika menghadapi tekanan dari luar individu merupakan cara tubuh mempertahankan keseimbangan tersebut (Sharkey dan Pittman, 1996). Lebih lanjut Cannon menyatakan bahwa ketegangan dan stress merupakan usaha tubuh manusia menjaga dan mengembalikan keseimbangan, seperti semula, meskipun hal itu seringkali menuntun pada munculnya ketegangan sekaligus mempengaruhi kondisi fisiologis (Dougall dan Baum, 2003). Penyataan Selye menunjukkan secara langsung kepada kita bahwa masing-masing individu memiliki kemampuan berbeda menghadapi tekanan dari luar, yang semuanya bertumpu pada interaksi rumit di poros HPA (Dougall dan Baum, 2003). Karena itu, sejumlah efek samping yang muncul ketika individu sedang mengalami stress, dijelaskan oleh Selye, sebagai penyakitpenyakit akibat adaptasi (diseases of adaptation), atau lebih tepat disebut sebagai penyakitpenyakit akibat salah adaptasi (diseases of maladaptation) (McEwen, 1996). John W. Mason menjadi ilmuwan ketiga yang membangun pemahaman tentang stress dan perubahan kondisi fisologis. Mason berpandangan bahwa setiap stressor (penyebab stress) memicu perubahan berbeda dalam tubuh, namun demikian perubahan emosi, seperti kecemasan dan ketakutan tidak secara khusus berhubungan dengan stressor tersebut, sedehananya, perubahan emosional yang berbeda-beda dirasakan sama saja, ketika menghadapi kondisi situasi yang berbeda (Dougall, dan Baum, 2003). Lebih lanjut ia berpandangan bahwa stress merupakan proses tubuh ketika mempertahankan tingkat glukosa dalam tubuh, sebagai persiapan menghadapi perubahan jangka panjang - akibat tekanan lingkungan sekitar (Dougall dan Baum, 2003). Pandangan ketiga 


\section{Jurnal Komunikasi Nusantara}

\section{E-ISSN. 2685-7650}

Vol. 2 No. 2 (2020), pp 1-19

DOI: https://doi.org/10.33366/jkn.v2i2.46

ilmuwan di atas, meskipun berbeda secara prespektif, namun bertumpu pada premis yang sama, yaitu stress merupakan usaha tubuh menghadapi perubahan kondisi dan tekanan lingkungan sekitarnya, dengan cara mengubah-ubah konfigurasi fisiologis tubuh manusia, melalui interaksi biokimia tubuh dengan mekanisme neurologis. Kondisi demikian berlaku secara umum pada semua individu ketika menghadapi tekanan lingkungan.

Masa WFH berpotensi meningkatkan kemungkinan individu mengalami stress dan ketegangan, yang mungkin tidak terjadi pada kondisi normal. Keharusan individu berdaptasi secara mendadak dengan bentuk-bentuk komunikasi media digital di semua lini pekerjaan berpotensi besar menjadi stressor yang membawa individu pada kondisi stress. Kenyataan demikian juga didukung oleh fakta bahwa beban pekerjaan yang harus diselesaikan kemungkinan besar juga berlipat ganda, sehingga memungkinkan individu mengalami peningkatan ketegangan dan stress. Keadaan-keadaan demikian membangun kondisi yang sesuai bagi perubahan perilaku individu, perubahan psikologis dan emosional, serta perubahan pada perilaku komunikasi.

\section{Metode Penelitian}

Penelitian merupakan penelitian eksploratif, yang secara khusus menggunakan paradigma interpretatif sekaligus pendekatan riset partisipatoris. Pendekatan riset partispatoris memungkinkan peneliti terlibat secara langsung ke dalam obyek penelitian, sehingga peneliti bisa menjadi bagian yang diteliti. Thomas Jacobson (2008) mengatakan bahwa pendekatan riset partispatoris merupakan riset dengan tingkat objetivitas rendah, karena riset tersebut melibatkan keikutsertaan peneliti atau kelompok masyarakat tertentu dalam proses penelitian sekaligus menjadi obyek penelitian tersebut. Dengan kata lain, riset partispatoris merupakan riset tentang diri sendiri atau kelompok masyarakat itu sendiri. Hal serupa juga dijelaskan oleh Steve Jordan (2008), yang menjelaskan bahwa riset partisipatoris umumnya sangat lentur, bahkan peneliti bisa menentukan metode penelitiannya sediri, yang dirasa tepat untuk hal itu. Jordan (2008) juga menjelaskan bahwa rentang metodologi riset partisipatoris terentang pada sejumlah disiplin ilmu sosial, seperti sosiologi, sosiopsikologi, marxisme, feminisme, dan lain-lain. Selama ini, riset partisipatoris dilakukan oleh kelompok masyrakat tertentu untuk mengamati bentuk-bentuk pergerakan atau perubahan sosial dalam masyarakat tersebut (Jacobson, 2008). Namun demikian artikel ini menggunakan riset partisipatoris sebagai pendekatan metodologis, karena secara langsung mengamati perubahan kondisi fisiologis dan perilaku komunikasi pada diri penulis. Akan tetapi, hasil artikel ini diharapkan bisa menjadi landasan bagi artikel-artikel atau penelitian-penelitian di kajian Communibiology.

Pengumpulan data dilakukan menggunakan pengumpulan data secara eksperimental, yang mengkomparasikan dua kelompok pengujian, yang dilakukan dengan cara memberikan perlakuan pada satu kelompok, sedangkan kelompok lainnya tidak diberikan perlakuan apapun. Penggunaan metode ini dilakukan menggunakan dua tahapan penting, pertama peneliti mengambil data dengan melakukan perlakukan tertentu kepada subyek penelitian; kedua, peneliti mengambil data dari subyek tanpa perlakuan tertentu, yang digunakan sebagai kelompok kontrol. Pada pengambilan data pertama, subyek diberikan perlakukan (treatment) berupa puasa (tidak memberikan makanan selama sekitar 11-12 jam), sehingga diharapkan perubahan fisiologis 


\section{Jurnal Komunikasi Nusantara}

E-ISSN. 2685-7650

Vol. 2 No. 2 (2020), pp 1-19

DOI: https://doi.org/10.33366/jkn.v2i2.46

akibat makanan bisa dieliminasi. Pada dasarnya, makanan bisa memberikan pegaruh besar pada kondisi fisiologis individu, seperti garam yang meningkatkan tekanan darah, dan gula yang meningkatkan ketegangan dan stress (Pryce, 2005). Sementara itu, pada pengambilan data kedua, subyek tidak diberikan perlakuan apapun (data kontrol), yaitu dibebaskan makan beragam makanan secara normal dalam periode makan harian (sarapan, makan siang, dan makan malam), termasuk juga membolehkan makan kudapan (makanan ringan) di luar waktu makan harian tersebut. Perbandingan dua data di atas diguanakan untuk melihat munculnya kemungkinan munculnya perubahan data fisiologis di luar pengaruh makanan, terutama pada saat subyek mendapatkan perlakukan (eksperimen/treatment). Dengan demikian penulis bisa memperkirakan bahwa variasi data psikologis individu ketika WFH, saat berpuasa, kemungkinan besar tidak disebabkan oleh makanan.

Artikel ini menggunakan sumber data utama berupa fenomena sosial berupa perilaku komunikasi dan fenomena biologis berupa fluktuasi nilai-nilai fisiologis. Karena itu penelitian ini menggunakan jenis data primer yang diperoleh langsung dari diri penulis berupa kondisi fisiologis dan perilaku komunikasi. Penggunaan sumber data berupa fenomena sosial dan fenomena biologis, serta jenis data primer memberikan penulis potensi besar untuk mendapatkan data secara mudah, karena dilakukan tanpa penggunaan prosedur perizinan formal yang rumit. Selain itu pengumpulan data bisa dilakukan secara langsung, di rentang waktu yang ditentukan sepenuhnya oleh penulis. Lebih jauh penulis bisa mengamati perilaku komunikasi yang dilakukan oleh penulis sendiri, selama menjadi obyek penelitian. Dengan demikian penulis bisa mendapatkan data secara valid dan dalam waktu yang relatif singkat, jika dibandingkan jika penulis harus turun ke lapangan penelitian di lingkungan sosial. Setidaknya ada dua data utama yang digunakan dalam artikel ini, yaitu perilaku komunikasi dan data fisiologis berupa tekanan darah dan denyut nadi. Kondisi demikian menuntut peneliti menggunakan teknik pengumpulan data berupa observasi partisipan aktif, dan pencatatan data fisiologis berupa tekanan darah dan fluktuasi denyut nadi menggunakan sfigmomanometer (dikenal juga dengan nama umum tensimeter) digital terkalibrasi, karena itu secara teknis bisa dipastikan bahwa semua nilai yang ditunjukkan oleh sfigmomanometer sudah valid dan reliabel. Penggunaan alat diagnosis bantu berupa sfigmomanometer digital digunakan untuk mencatat dua indikator fisiologis dasar, yaitu tekanan darah dan denyut nadi bisa menjadi indikator utama dari ketegangan dan stress (Coste, Murray, dan Stenzel-Poore, 2005). Lebih lanjut ketegangan dan stress bisa secara langsung atau secara tidak langsung bisa mempengaruhi kemampuan manusia berkomunikasi, karena stress dan ketegangan menjadi bagian dari gangguan dalam diri individu.

\section{Hasil dan Pembahasan}

\section{Analisis terhadap kondisi fisiologis individu}

Pengamatan penulis pada perilaku komunikasi dan kondisi fisiologi penulis sendiri selama sekitar 14 hari menghasilkan sejumlah temuan relatif penting. Sejumlah temuan tersebut terdiri dari perilaku komunikasi penulis dengan lingkungan keluarga dan lingkungan kerja dalam waktu hampir bersamaan, dan fluktuasi sejumlah data fisiologis tubuh individu berupa tekanan darah dan denyut nadi. Fluktuasi nilai indikator fisiologis dipengaruhi oleh beragam faktor penting seperti konsumsi makanan, aktivitas harian, hingga tekanan lingkungan. Untuk 


\section{Jurnal Komunikasi Nusantara}

E-ISSN. 2685-7650

Vol. 2 No. 2 (2020), pp 1-19

DOI: https://doi.org/10.33366/jkn.v2i2.46

mengurangi bias pada data psikologis, penulis mengeliminasi pengaruh makanan sebagai faktor pengaruh pada perubahan nilai indikator data fisiologis, karena penulis sedang melakukan puasa (puasa Ramadhan), sehingga secara asumsional hanya ada dua faktor penting yang berpengaruh pada perubahan nilai indikator fisiologis, yaitu aktivitas harian dan tekanan lingkungan — dalam kondisi ini berkaitan dengan aktivitas WFH. Namun demikian, pada pengambilan data kedua sebagai pembanding, peneliti melakukan aktivitas normal dalam WFH - peneliti tidak berpuasa dan melakukan kebiasaan secara normal. Hal itu menjadikan perubahan kondisi fisiologis dipengaruhi oleh lebih banyak faktor. Dengan demikian peneliti bisa memperkirakan secara lebih akurat bahwa perubahan kondisi fisiologis ketika WFH, saat pengambilan data pertama, kemungkinan besar berkaitan dengan ketegangan dan atau stress.

Aktivitas harian dan tekanan lingkungan sebagain besar berhubungan dengan situasi dan kondisi yang sedang terjadi. Selama masa WFH, mayoritas aktivitas harian dan aktivitas pekerjaan penulis dilakukan dari rumah, yang notabene membutuhkan sarana pendukung dan fasilitas memadai. Kurangnya kualitas sarana pendukung dan fasilitas jaringan internet bisa menjadi stressor bagi subyek penelitian, yang notabene menjadi penyebab dari munculnya ketegangan fisik dan psikologis. Sayangnya, kualitas sarana dan fasilitas internet, untuk mendukung kerja subyek, belum dimiliki, padahal sebagian besar pekerjaan subyek harus dikerjakan menggunakan internet. Hal demikian memunculkan kondisi pelik, yakni, pekerjaan yang sejatinya bisa dikerjakan secara baik dalam waktu singkat berubah menjadi pekerjaan yang rumit dan membutuhkan waktu kerja lebih lama-karena proses penyelesaian pekerjaan menggunakan internet ada kalanya membutuhkan waktu kerja lebih lama dibandingkan dengan penyelesaikan pekerjaan secara konvensional. Selain itu, beban pekerjaan yang harus diselesaikan menjadi dua kali lebih banyak, karena setiap individu yang melaksanakan WFH harus menyelsaikan beban pekerjaan rumah dan beban pekerjaan kantor sekaligus dalam waktu hampir bersamaan.

Kajian communibiology dibangun berdasarkan empat perspektif utama, yaitu kaitan komunikasi dengan empat kajian utama yang menggabungkan pandangan biologi, kedokteran dan komunikasi, yaitu perspektif genetik, perspektif endokrinologis, perspektif biososial, dan perspektif communibiology. Lebih jauh, pandangan communibiology dari Beatty dan McCroskey sejatinya dibangun berdasarkan hasil dan temuan dari kajian-kajian dalam ilmu biologi dan kedokteran, yaitu kajian endokrinologis dan kajian neurologis, yang keduanya menyusun mayoritas dari aktivitas fisiologis dalam tubuh manusia. Sebagaimana dijelaskan sebelumnya bahwa interaksi dari aspek endokrinologis dan neurologis memberikan pengaruh besar pada kondisi tubuh dan perilaku, seperti yang disampaikan oleh Cannon, Selye, dan Mason. Pemikiran-pemikiran tersebut membangun pemahaman tentang kaitan erat antara aspek endokrinologis dan neurologis, yang ditunjukkan dengan mekanisme dalam otak dengan interkasinya dengan aspek pendukungnya — sistem saraf tepi dan sistem endokrin (Tonacci, et al, 2019). Artikel ini menggunakan perspektif communibiology dari Beatty dan McCroskey, yang sejatinya menunjukkan secara detail tentang mekansime interaksi antara aspek endokrinologis dan neurologis dalam diri manusia, yang berkaitan dengan perubahan komunikasi individu dalam keluarga, ketika aktivitas WFH. 


\section{Jurnal Komunikasi Nusantara}

\section{E-ISSN. 2685-7650}

Vol. 2 No. 2 (2020), pp 1-19

DOI: https://doi.org/10.33366/jkn.v2i2.46

Pada umumnya bentuk-bentuk ketegangan dan stress ditandai oleh sejumlah indikasi penting yang ditunjukkan oleh perubahan sejumlah indikator fisiologis, termasuk di antaranya ialah fluktuasi nilai tekanan darah dan denyut nadi. Perhatikan grafik di bawah ini.

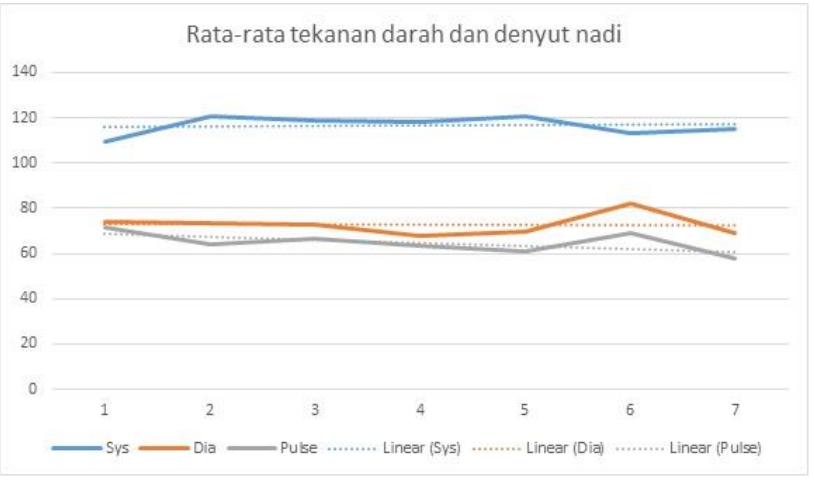

(a) Nilai rata-rata tekanan darah dan denyut nadi subyek saat diberikan perlakukan (eksperimen/treatment)

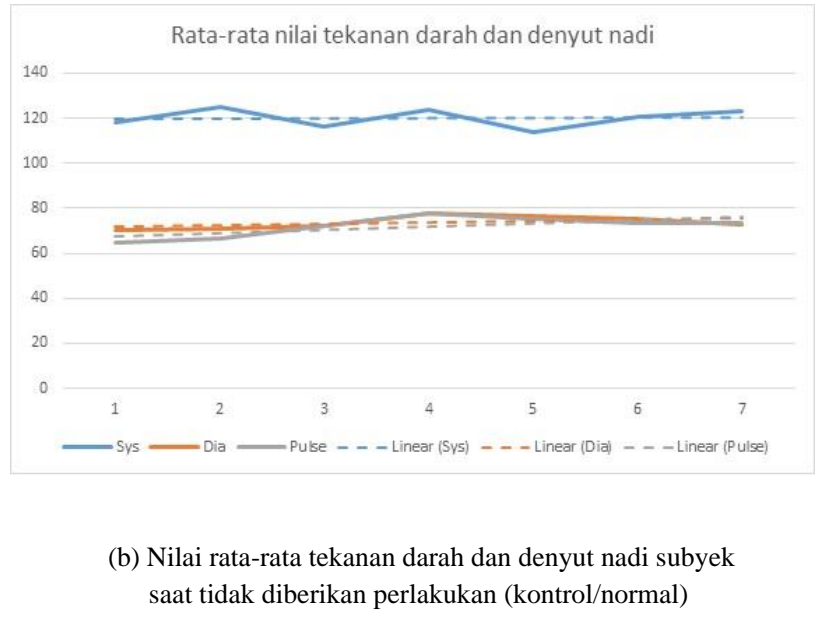

Diagram 2. Distribusi data fisiologis tekanan darah dan denyut nadi rata-rata: Data fisiologis di atas merupakan komparasi data nilai fisiologis subyek (penulis), berupa data rata-rata dalam kurun waktu 14 hari selama proses WFH (WFH). Secara rata-rata tampak bahwa tekanan sistol tampak stabil, namun secara tren mengalami peningkatan relatif kecil sepanjang kurun 7 hari, Sementara itu, tekanan diastol mengalami fluktuasi, namun secara tren menunjukkan stabilitas. Sedangkan denyut nadi rata-rata mengalami penurunan relatif besar. Namun pada 7 hari berikutnya, tekanan sistol relatif stabil tanpa penurunan atau kenaikan berarti, sedangkan nilai distol dan denyut nadi mengalami peningkatan secara bertahap namun pada akhir hari cenderung stabil . (sumber: diolah oleh penulis)

Diagam di atas menunjukkan dinamika tekanan darah subyek-penulis — selama proses pelaksanaan aktivitas WFH. Tekanan darah individu diukur menggunakan perbandingan tekanan sistol (systole disingkat dengan sys) — tekanan jantung ketika kontraksi, atau pada saat memompa darah ke seluruh tubuh_dan tekanan diastol (diastole disingkat dengan dia) — tekanan jantung ketika relaksasi, atau ketika menarik darah ke dalam jantung (Antoni, 1996). Perbandingan tekanan sistol dan diastol menunjukkan dinamika tekanan darah pada mayoritasi individu, dalam konteks ini, perbandingan nilai sistol dan diastol menunjukkan ritme harian subyek penelitian. Secara umum manusia normal memiliki tekanan darah pada rentang tekanan sistol $117 \mathrm{mmHg}$ dan tekanan diastol $70 \mathrm{mmHg}$, atau biasa di tulis dengan 117/70 mmHg (Greger dan Bleich, 1996), namun demikian manusia normal pada rentang usia 20-40 tahun tidak boleh memiliki tekanan darah lebih dari 150/100 mmHg (Greger dan Bleich, 1996). Karena itu fluktuasi nilai tekanan darah untuk tekanan sistol antara 110-130 mmHg, sementara rentang antara 60-80 mmHg untuk diastol, masih bisa dikatakan normal. Diagram 2 menunjukkan nilai rata-rata tekanan darah penulis dalam waktu 14 hari. Kurun waktu 14 hari dibagi menjadi dua bagian besar, yaitu tujuh hari ketika subyek diberikan perlakuan, berupa puasa, ditunjukkan pada diagram 2 (a), dan tujuh hari berikutnya sebagai nilai kontrol, ketika subyek tidak diberikan perlakuan sama sekali, sebagaimana ditunjukkan pada diagram 2 (b). Pada dua diagram di atas tampak jelas bahwa dinamika tekanan darah masih dalam batas normal, namun mengalami fluktuasi yang sangat dinamis, antara huruf (a) dan huruf (b). 


\section{Jurnal Komunikasi Nusantara}

E-ISSN. 2685-7650

Vol. 2 No. 2 (2020), pp 1-19

DOI: https://doi.org/10.33366/jkn.v2i2.46

Pada diagram 2 (a) di tujuh hari pertama menunjukkan tekanan sistol subyek mengalami tren peningkatan dari hari 1 hingga hari 7, meskipun nilai peningkatan tersebut sangat rendah. Tren peningkatan nilai tekanan sistol berada pada rentang antara 115-118 mmHg, selama tujuh hari. Peningkatan tren nilai tekanan rata-rata sistol selama tujuh hari menunjukkan bahwa subyek kemungkinan besar mengalami peningkatan nilai metabolisme harian, yang mungkin dipengaruhi oleh aktivitas harian, dan juga perlakuan yang diterima oleh subyek penelitian. Kondisi demikian boleh jadi dipengaruhi oleh kehadiran TH (tyroid hormone), yang secara langsung mampu meningkatkan tekanan sistol dan mengurangi tekanan diastol (Finke, Schleusener, dan Heirholzer, 1996). Peran TH dalam diri subyek semakin tampak jelas, karena secara umum subyek mengalami peningkatan nilai rata-rata sistom, sementara tekanan rata-rata diastol mengalami penurunan-meskipun dalam rentang sangat rendah antara 76-74 $\mathrm{mmHg}$ selama kurun waktu tujuh hari, meskipun pada hari 6, tekanan sistol meningkat menjadi 82 mmHg, kemudian pada hari 7, tekanan sistol turun menjadi $70 \mathrm{mmHg}$. Kondisi demikian kemungkinan dipengaruhi oleh dinamika jumlah TH dalam darah juga berkaitan dengan dinamika kadar hormon-hormon steroid dalam darah (Finke, Schleusener, dan Heirholzer, 1996) - kelas hormon steorid bersama-sama dengan TH bertanggungjawab pada metabolisme individu. Namun demikian nilai rata-rata denyut nadi penulis juga menurun secara bertahap dalam tujuh hari, yang berada pada rentang nilai 70-60 bpm.

Sementara itu, fluktuasi nilai rata-rata ketika subyek tidak diberikan perlakuan, pada tujuh hari berikutnya, 2 (b), menunjukkan variasi nilai dan tren yang cenderung stabil. Pada diagram 2 (b), nilai sistol berada pada rata-rata variasi nilai di $120 \mathrm{mmHg}$ dalam rentang waktu sekitar lima hari, sementara nilai diastol dan denyut nadi juga berada pada tren yang relatif stabil pula, tanpa fluktuasi nilai yang tajam. Tren nilai sistol, diastol, dan denyut nadi yang cenderung stabil pada rentang waktu tujuh hari kemungkinan besar menunjukkan adanya kestabilan metabolisme harian individu, karena individu bisa mendapatkan asupan nutrisi secara normal, serta dinamika harian yang cenderung bisa diselesaikan secara normal oleh subyek. Di samping itu pada rentang tujuh hari tersebut, hampir tidak ada tekanan berat dari lingkungan yang diterima oleh individu, sehingga tingkat hormon-hormon steroid berada pada batas normal. Asupan makanan dan nutrisi yang diterima oleh subyek bisa jadi ikut serta mempengaruhi jumlah hormon steroid dalam tubuh, sehingga nilai-nilai fisiologis dalam diri subyek menunjukkan nilai yang cenderung stabil.

Komparasi dua data di atas diagram 2 (a) dan (b) menunjukkan sesuatu hal yang menarik, sekaligus menjadikan penulis bisa menarik kesimpulan sederhana. Variasi nilai dan fluktuasi nilai fisiologis individu saat subyek diberikan perlakukan (berupa puasa) ternyata tidak diakibatkan oleh asupan makanan, tapi karena tekanan pekerjaan yang tinggi. Secara umum kondisi subyek ketika puasa secara asumsional kemungkinan besar memberikan pengaruh berupa penurunan nilai-nilai fisiologis tubuh, karena perlambatan metabolisme, akan tetapi ketika subyek sedang berpuasa justru muncul perubahan indikasi peningkatan dan penurunan relatif nilai rata-rata tekanan darah dan denyut nadi harian. Keadaan demikian kemungkinan besar tidak berhubungan dengan puasa yang dilakukan oleh subyek, tapi kemungkinan besar dipengaruhi oleh faktor tekanan lingkungan luar, berupa pekerjaan atau hal-hal lainnya. Sementara itu pada data kontrol, semua nilai rata-rata indikator fisiologis berupa tekanan darah 


\title{
Jurnal Komunikasi Nusantara
}

\section{E-ISSN. 2685-7650}

Vol. 2 No. 2 (2020), pp 1-19

DOI: https://doi.org/10.33366/jkn.v2i2.46

dan denyut nadi menunjukkan tren stabil, karena saat itu subyek melakukan aktivitas secara normal, serta melakukan aktivitas makan seperti biasa. Kestabilan nilai rata-rata tekanan darah dan denyut nadi kemungkinan besar juga berkaitan dengan rendahnya tingkat ketegangan dan stress yang diterima individu.

Perubahan nilai tekanan darah dan denyut nadi subyek ketika WFH, sejatinya bisa dimulai dari pengamatan variasi nilai tekanan darah dan denyut nadi subyek, untuk menentukan titik tumpu pengukuran di rentang waktu lainnya (siang dan malam). Karena itu dinamika perubahan nilai tekanan darah dan denyut nadi, sebagai indikator fisiologis utama yang diamati dalam artikel ini, merupakan tumpuan bagi pengukuran selanjutnya, karena itu perbandingan fluktuasi nilai tekanan darah dan denyut nadi selama sekitar 14 hari memberikan gambaran awal tentang kondisi fisik subyek ketika memulai aktivitas harian, atau sebelum memulai pekerjaan. Menariknya, perbandingan pada diagram 3 (a) dan diagram 3 (b) menunjukkan kondisi yang hampir serupa, meskipun ada sejumlah perbedaan, khusunya pada tekanan diastol dan denyut nadi. Perhatikan diagram di bawah ini

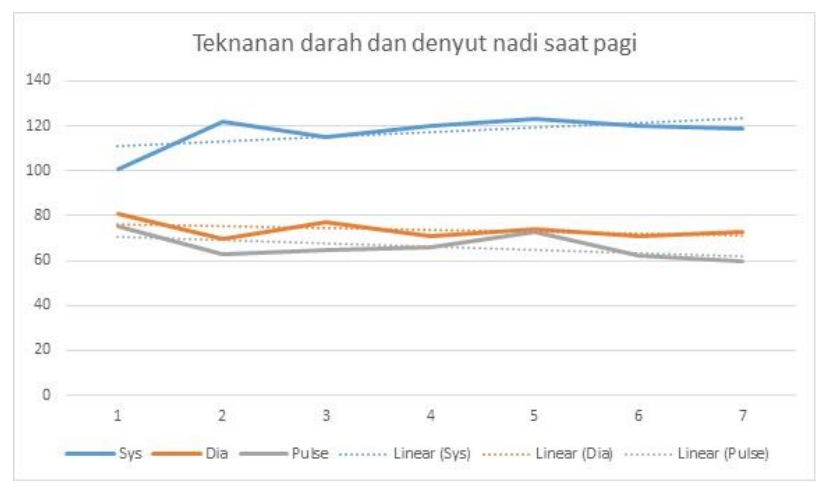

(a) Nilai tekanan darah dan denyut nadi subyek saat pagi hari saat diberikan perlakukan (eksperimen/treatment)

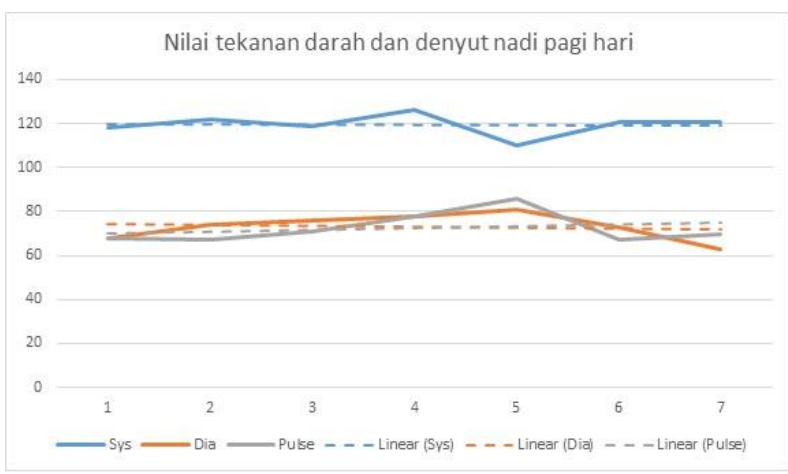

(b) Nilai tekanan darah dan denyut nadi subyek saat pagi hari saat tidak diberikan perlakukan (kontrol/normal)

\begin{abstract}
Diagram 3. Distribusi data fisiologis tekanan darah dan denyut nadi saat pagi hari: Saat pagi, variasi tekanan darah dan denyut nadi mengalami dinamika relatif menarik selama kurun 14 hari. Pada 7 hari pertama tampak jelas individu mengalami peningkatan sistol, penurunan diastol dan denyut nadi. Kondisi demikian kemungkinan besar berkaitan dengan tingkat metabolisme yang tinggi pada pagi hari dan peningkatan kadar TH dalam darah, hal itu kemungkinan besar dipicu oleh prakondisi stress dalam individu, karena dalam kondisi menghadapi tekanan pekerjaan. Sebagai pembanding, 7 hari berikutnya menunjukkan sistol, diastol, dan denyut nadi pada tren relatif stabil pada semua indikator meskipun terjadi fluktuasi nilai yang tidak terlalu signifikan pada hari ke 5, 6 dan 7. (sumber: diolah oleh penulis).
\end{abstract}

Diagram 3 (a) secara umum menunjukkan bahwa ada perubahan signifikan peningkatan nilai tekanan sistol secara bertahap selama kurun waktu 7 hari. Sedangkan nilai tekanan diastol dan nilai denyut nadi mengalami penurunan secara signifikan pula. Kondisi demikai memberikan indikasi penting bahwa penulis mengalami tingkat metabolisme yang relatif tinggi pada pagi hari, yang secara langsung melibatkan peningkatan kadar $\mathrm{TH}$ dan hormon-hormon steroid. Meskipun saat itu subyek tidak menerima asupan makanan, namun tekanan lingkungan bisa jadi memicu peningkatkan TH dan hormon-hormon steroid. Selain itu, peningkatan nilai sistol pada 


\section{Jurnal Komunikasi Nusantara}

\section{E-ISSN. 2685-7650}

Vol. 2 No. 2 (2020), pp 1-19

DOI: https://doi.org/10.33366/jkn.v2i2.46

pagi hari secara drastis dalam waktu tujuh hari memberikan isyarat bahwa individu mengalami sejumlah gejala ketegangan dan atau stress, meskipun masih dalam tingkat yang relatif rendah. Hal demikian muncul karena kondisi fisiologis individu seakan-akan bersiap menerima tekanan pekerjaan harian, yang hadir pada hari itu. Dengan kata lain, individu seakan bersiap merasakan semacam ketegangan ketika harus menghadapi pekerjaan harian, yang terdiri dari aktivitas harian di rumah, serta aktivitas pekerjaan kantor. Meskipun secara umum subyek tidak terlalu merasakan kecemasan dan kegugupan pada pagi hari, namun data fisiologis individu menunjukkan hal berbeda. Sehingga ada kemungkinan bahwa kondisi fisiologis mayoritas individu, termasuk juga penulis, merespon ketegangan lebih cepat lebih cepat, bahkan sebelum individu tersebut menyadari bahwa ia sedang berada pada kondisi tegang, cemas, dan atau stress. Hal itu berbeda dengan nilai-nilai yang ditunjukkan pada diagram 3 (b), yang secara umum menunjukkan bahwa kondisi fisiologis tubuh subyek berada pada rentang yang relatif stabil, yang mungkin disebabkan oleh sejumlah faktor penting, yaitu tingkat tekanan lingkungan yang relatif kecil, dan atau asupan makanan dan nutrisi yang relatif seimbang, atau faktor-faktor lain yang tidak teramati dalam penelitian ini. Namun demikian, tubuh subyek kemungkinan besar tetap mempersiapkan diri untuk menghadapi tekanan, ketegangan, dan atau stress, akan tetapi hal itu tidak memberikan perubahan nilai signifikan pada indikator fisiologis yang diamati, yaitu tekanan darah, dan denyut nadi.

Kemampuan tubuh individu merespon ketegangan dan stress lebih cepat, bahkan sebelum disadari oleh individu tersebut. Hal itu indikasi respon fisiologis indvidu dirancang untuk menyiapkan individu menghadapi tekanan dari lingkungan. Keadaan demikian mungkin merujuk pada prakondisi fisiologis tubuh manusia agar tubuh manusia lebih siap menghadapi kondisi tekanan lingkungan. Lebih lanjut, prakondisi fisiologis seperti itu bisa mempercepat kondisi individu menuju ketegangan dan stress, jika memang tekanan lingkungan yang dihadapi begitu besar, namun prakondisi tersebut tidak berubah menjadi ketegangan atau stress, jika tekanan lingkungan berhasil diatasi. Keadaan seperti itu menunjukkan bahwa tubuh bersifat dinamis, bahkan ketika individu harus menghadapi tekanan lingkungan sekitar. Diagram 4 (a) dan (b) di bawah ini menunjukkan fluktuasi data fisiologis saat siang hari.

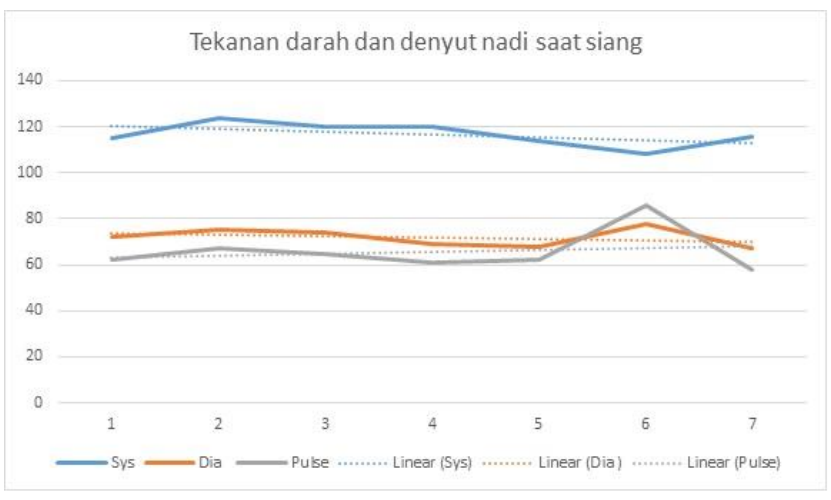

(a) Nilai tekanan darah dan denyut nadi subyek pada siang hari saat diberikan perlakukan (eksperimen/treatment)

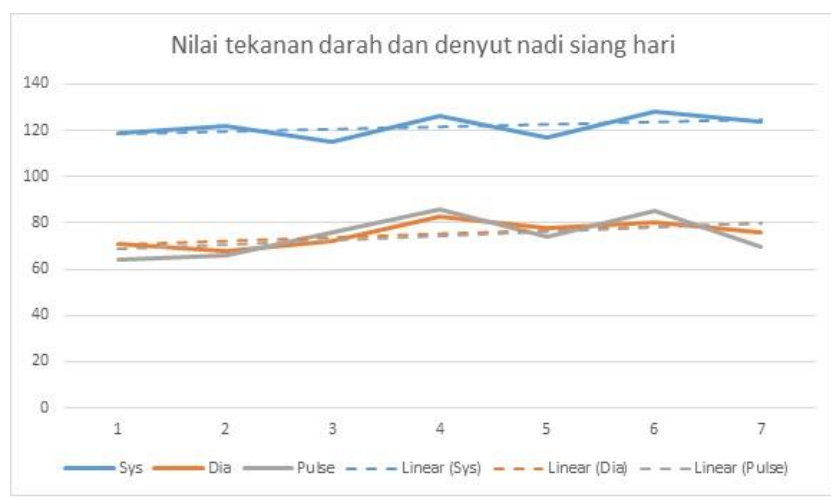

(b) Nilai tekanan darah dan denyut nadi subyek pada siang hari saat tidak diberikan perlakukan (kontrol/normal) 


\title{
Jurnal Komunikasi Nusantara
}

E-ISSN. 2685-7650

Vol. 2 No. 2 (2020), pp 1-19

DOI: https://doi.org/10.33366/jkn.v2i2.46

\begin{abstract}
Diagram 4. Distribusi data fisiologis tekanan darah dan denyut nadi saat siang: . Variasi nilai pada indikator fisiologis 7 hari pertama menunjukkan bahwa individu secara umum berada pada kondisi relatif stabil, namun secara fisiologis, tubuh individu seakan-akan masih bersiap-siap menghadapi tekanan dan stress yang mungkin akan muncul tiba-tiba. Hal itu ditandai dengan penurunan tren nilai sistol secara gradual dalam waktu 7 hari, sementara penurunan nilai diastol yang tidak terlalu signifikan. Namun demikian ada peningkatan tren nilai denyut nadi relatif tinggi yang terjadi secara bertahap mulai hari 5 dan 6. Sementara itu pada 7 hari berikutnya, sebagai perbandingan, nilai sistol, diastol, dan denyut nadi mengalami peningkatan nilai secara perlahan mulai dari hari ke 2 hingga hari ke 7. Tren nilai sistol meningkat secara gradual dari $70 \mathrm{mmHg}$ menuju $80 \mathrm{mmHg}$ dalam waktu tujuh hari, hal serupa terjadi juga pada tren nilai denyut nadi dari 65 bpm menuju 80 bpm. Hal itu menunjukkan bahwa dalam keadaan normal, saat siang hari merupakan kondisi umum terjadinya peningkatan nilai sistol, diastole, dan denyut nadi, yang semuanya mungkin berkaitan dengan aktivitas harian secara umum, atau asupan makanan. (sumber: diolah oleh penulis).
\end{abstract}

Diagram 4 (a) di atas menunjukkan perubahan nilai tekanan darah dan denyut nadi, berbeda dengan nilai tekanan darah dan denyut nadi saat padi hari. Pada siang hari tampak bahwa penurunan nilai rata-rata sistol, penurunan nilai rata-rata diastol, dalam kurun waktu tujuh hari, meskipun penurunan nilai rata-rata tidak terlalu signifikan. Menariknya dalam kurun waktu yang sama, terjadi peningkatan nilai denyut nadi dari sekitar $62 \mathrm{bpm}$ pada hari 1, namun terjadi peningkatan sekitar 89 bpm pada hari 6. Kondisi demikian membuat peningkatan nilai rata-rata denyut nadi selama tujuh hari sekitar 60-70 bpm. Perubahan-perubahan nilai fisiologis, seperti penurunan nilai sistol, peningkatan nilai diastol, dan peningkatan jumlah denyut nadi kemungkinan besar mengindikasikan bahwa individu berhasil mengatasi ketegangan akibat aktivitas harian, meskipun aktivitas metabolisme individu masih relatif tinggi pada siang hari. Secara sederhana, meskipun individu telah berhasil melalui tekanan lingkungan dalam kurun selama tujuh hari, namun fakta bahwa siang hari merupakan masa ketika metabolisme individu berada pada titik paling tinggi tidak bisa diabaikan, sehingga ada peningkatan nilai rata-rata denyut nadi pada siang hari selama sepekan. Peningkatan nilai rata-rata denyut nadi pada siang hari keumgkinan besar dipengaruhi oleh aktivitas sistem saraf simpatis, karena aktivitas harian individu (Antoni, 1996) — dalam hal ini individu umumnya sedang pada puncak aktivitas WFH. Namun demikian peningkatan nilai rata-rata denyut nadi dipengaruhi oleh perubahan waktu antara tekanan sistol dan diastol (Antoni, 1996). Diagram 4 (a) secara langsung menunjukkan bahwa meskipun individu berhasil mengatasi tekanan harian, namun reaksi fisiologis ketegangan individu tidak secara langsung mengalami penurunan aktivitas secara perlahan dan bertahap. Dengan demikian, tubuh diharapkan bisa lebih siap menghadapi perubahan tekanan lingkungan sewaktu-waktu.

Di sisi lain, diagram 4 (b) menunjukkan fakta penting bahwa ketika individu tidak diberikan perlakukan, nilai dan tren kondisi fisiologis menunjukkan peningkatan yang stabil dalam waktu tujuh hari. Kondisi demikian menguatkan dugaan peneliti bahwa kemungkinan besar makanan memberikan pengaruh pada peningkatan tren nilai-nilai fisiologis tersebut. Dengan begitu, peningkatan dan atau penurunan nilai fisiologis pada saat subyek diberikan perlakukan (diagram 4 (a)) hampir pasti ditentukan karena dua faktor dominan, yaitu perlakukan terhadap subyek itu sendiri, dan tekanan lingkungan kerja yang dirasakan oleh subyek, sat melakukan WFH. Kondisi demikian memberikan bukti empiris tentang dampak fisiologis yang diterima subyek ketika melakukan aktivitas WFH. Sementara itu, ketika subyek tidak diberikan 


\title{
Jurnal Komunikasi Nusantara
}

\section{E-ISSN. 2685-7650}

Vol. 2 No. 2 (2020), pp 1-19

DOI: https://doi.org/10.33366/jkn.v2i2.46

perlakukan pada diagram 4 (b), peneliti tidak bisa menggambarkan bahwa nilai-nilai fisiologis yang meningkat secara bertahap, disebabkan oleh dua faktor penting yang semuanya saling memberikan pengaruh besar, yaitu makanan dan beban kerja WFH, sehingga peneliti tidak bisa membedakan secara jernih faktor mana yang paling berpengaruh di antara keduanya.

Secara asumsional, tekanan darah dan denyut jantung individu pada malam hari mengalami penurunan secara bertahap. Namun demikian diagram 5 (a) dan (b) di bawah ini menujukkan variasi nilai yang relatif menarik. Diagram 5 (a) menunjukkan penurunan nilai tekanan sistol pada malam hari berada pada rentang yang sangat rendah dalam waktu tujuh hari, sekitar 119-117 mmHg. Sementara itu nilai diastol pada malam hari mengalami peningkatan signifikan dalam tempo tujuh hari pertama, sekitar 69-79 $\mathrm{mmHg}$. Sedangkan nilai denyut nadi mengalami penurunan sangat drastis dari 78 bpm pada hari 1 menjadi sekitar 57 bpm pada hari ke 7. Semua perubahan nilai fisiologis individu pada malam hari menunjukkan bahwa individu mengalami dinamika aktivitas pada malam hari, yang kemungkinan besar berhubungan dengan keadaan yang akan dihadapi pada hari selanjutnya.

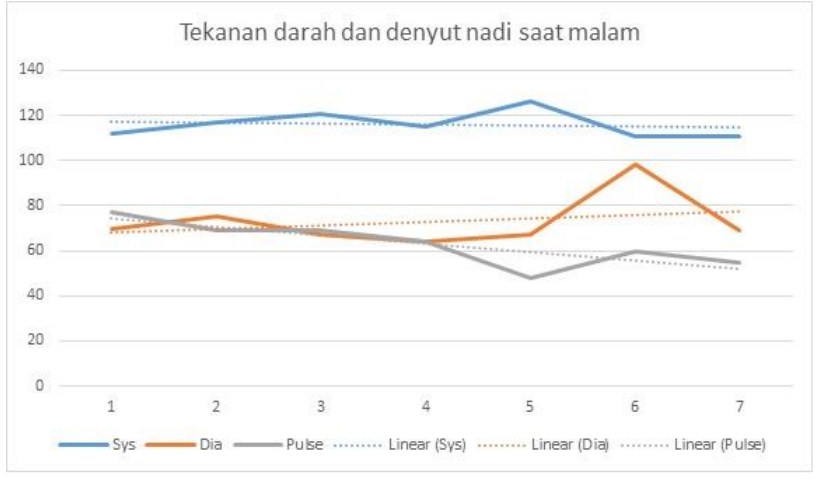

(a) Nilai rata-rata tekanan darah dan denyut nadi subyek saat diberikan perlakukan (eksperimen/treatment)

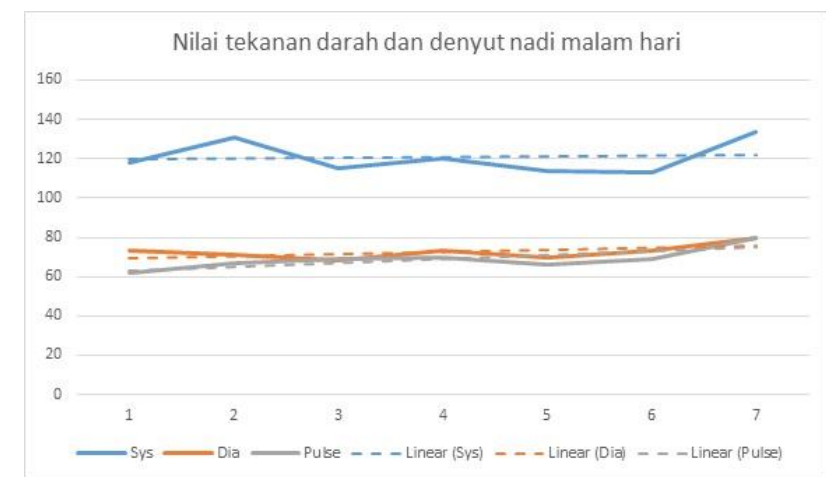

(b) Nilai rata-rata tekanan darah dan denyut nadi subyek saat tidak diberikan perlakukan (kontrol/normal)

\begin{abstract}
Diagram 5. Distribusi data fisiologis tekanan darah dan denyut nadi saat malam: Saat malam hari, tubuh individu mengalami penurunan metabolisme sangat tajam, yang ditandai dengan sejumlah indikasi penting, termasuk penurunan tekanan sistol yang tidak signifikan dalam kurun waktu 7 hari, namun ada peningkatan tajam nilai diastol. Sementara itu ada penurunan sangat tajam pada denyut nadi. Kondisi seperti itu seakan-akan menunjukkan bahwa tubuh individu berada dalam pascakondisi stress, namun tetap dalam kondisi persiapan untuk menghadapi tekanan pada keesokan hari. Sebagai pembanding, 7 hari berikutnya dalam kondisi normal, semua indicator fisiologis yang diamatai berada pada tren relatif stabil. Meskipun ada peningkatan pada nilai tren sistol dan denyut nadi, namun semuanya hampir tidak banyak mengalami variasi nilai, jika dibandingkan dengan kondisi ketika subyek diberikan perlakuan. (sumber: diolah oleh penulis).
\end{abstract}

Peningkatan nilai diastol dan penurunan denyut nadi pada malam hari bisa jadi berhubungan dengan rendahnya aktivitas metabolisme tubuh individu pada malam hari, yang secara umum masuk pada masa istirahat. Namun demikian tubuh individu tidak sepenuhnya mengalami masa istirahat, karena sejumlah aktivitas fisiologis menunjukkan bahwa tubuh individu sedang dalam masa pascakondisi setelah aktivitas harian - masa istirahat. Pascakondisi tubuh individu, secara fisiologis seakan-akan disiapkan untuk kembali masuk pada tahapan prakondisi di hari selanjutnya, karena itu, pada malam hari tingkat stress individu berada dalam tingkat rendah, 


\section{Jurnal Komunikasi Nusantara}

E-ISSN. 2685-7650

Vol. 2 No. 2 (2020), pp 1-19

DOI: https://doi.org/10.33366/jkn.v2i2.46

namun tidak benar-benar hilang. Pada umumnya kehadiran stressor cenderung meningkatkan aktivitas sistem saraf simpatis, serta menghambat sistem saraf parasimpatis, sehingga menghasilkan sejumlah efek fisiologis, seperti peningkatan tekanan darah, percepatan denyut jantung, dan sebagainya (Ellenbroek, Geven, dan Cools, 2005). Indikasi bahwa individu berada pada kondisi stress ditunjukkan oleh peningkatan signifikan nilai diastol pada malam hari, yang mengindikasikan bahwa jantung sedang aktif memasukkan darah ke jantung, namun nilai sistol yang mengalami cenderung stabil-meskipun mengalami penurunan, menunjukkan bahwa individu mengalami tingkat metabolisme dan tingkat stress rendah. Hal demikian dikuatkan dengan penurunan nilai denyut nadi secara signifikan, dari hari 1 hingga hari 7 . Kondisi tingkat stress yang rendah yang dirasakan oleh individu kemungkinan besar berkaitan dengan rendahnya kadar hormon-hormon yang berkaitan dengan stress, seperti adrnaline, cortisol, TH, dan sebagainya, pada malam hari.

Sementara itu, pada diagram 5 (b) menunjukkan dinamika data fisiologis sejak hari 1 hingga hari 7, namun tetap menunjukkan tren data yang relatif stabil. Stabilitas tren data fisiologi saat malam hari kemungkinan berkaitan dengan kondisi tubuh dan stabilitas hormonal karena secara logis, malam hari merupakan masa ketika kondisi tubuh individu—subyek-dalam kondisi rileks (dengan kondisi metabolisme lambat). Namun demikian, secara spesifik, nilai diastol dan denyut nadi mengalami peningkatan namun relatif tidak signifikan, dalam waktu 7 hari nilai sistol meningkat dari $70 \mathrm{mmHg}$ menjadi $80 \mathrm{mmHg}$, sementara nilai denyut nadi meningkat dari $60 \mathrm{bpm}$ menuju $80 \mathrm{bpm}$. Peningkatan nilai diastol dan denyut nadi kemungkinan dipengaruhi oleh faktor-faktor lain yang mungkin tidak teramati dalam pengukuran data. Secara umum, irama denyut nadi dan tekanan darah berhubungan dengan reaksi neurologis dan endokrinologis, akibat beragam faktor, terutama makanan atau asupan nutrisi yang diterima subyek. Meskipun begitu, reaksi tubuh subyek tampaknya tetap mempersiapkan kondisi internal untuk menghadapi tekanan yang mungkin dirasakan pada hari berikutnya.

Temuan variasi data fisiologis individu di atas menunjukkan bahwa pada hakekatnya individu mampu melakukan proses adaptasi terhadap kondisi lingkungan yang secara umum menekan individu, khususnya selama proses WFH. Pada dasarnya, proses WFH-atau mengerjakan tugas-tugas kantor di rumah-bukan sesuatu yang serius, karena sebagian individu seringkali melakukan hal demikian. Akan tetapi, penggunaan media digital, internet dan $e$ communication secara terus-menerus selama proses WFH bisa memunculkan potensi ketegangan, karena proses adaptasi berkelanjutan terhadap semua teknologi tersebut. Namun ada kemungkinan ketika tubuh subyek bisa melakukan adaptasi terhadap tekanan lingkungan, maka tekanan tersebut, terutama pada masa WFH, tidak menghasilkan ketegangan hingga stress. Namun demikian keberhasilan individu berdapatasi dengan gaya hidup WFH, merupakan hasil dari proses adaptasi panjang penuh ketegangan dan stress. Kondisi seperti itu bagi sebagian individu menjadi stressor yang memunculkan gejala-gejala ketegangan dan stress, khususnya bagi individu yang tidak terlalu mampu beradaptasi dengan penggunaan internet atau $e$ communication secara terus-menerus, selama masa WFH. Karena itu, sejumlah temuan data di atas bisa bervariasi pada setiap individu, selama masa WFH. 


\section{Jurnal Komunikasi Nusantara}

E-ISSN. 2685-7650

Vol. 2 No. 2 (2020), pp 1-19

DOI: https://doi.org/10.33366/jkn.v2i2.46

\section{Analisis terhadap perilaku komunikasi selama proses penelitian}

Perubahan-perubahan fisiologis pada diri individu memberikan andil relatif besar pada perubahan perilaku komunikasi individu selama masa WFH. Pengamatan perubahan kondisi fisiologis individu selama 14 hari, serta pengamatan perilaku komunikasi individu selama pekan yang sama, menunjukkan gejala munculnya perubahan perilaku komunikasi, meskipun mungkin tidak sepenuhnya signifikan. Perubahan perilaku komunikasi meliputi dua bentuk komunikasi umum yang dikenal, yaitu perilaku komunikasi nonverbal dan perilaku komunikasi verbal. Kedua jenis perilaku tersebut secara spesifik dipengaruhi oleh perubahan-perubahan dalam kondisi fisiologis individu. Karena itu, dalam artikel ini, penulis menjelaskan perubahanperubahan perilaku komunikasi individu selama proses WFH pada dua jenis perilaku komunikasi, yaitu nonverbal dan verbal, dalam rentang waktu tujuh hari-selama subyek mendapatkan perlakuan atau treatment.

Perubahan pada perilaku komunikasi nonverbal merupakan bentuk perilaku komunikasi pertama yang diamati oleh penulis. Pada dasarnya aktivitas perilaku komunikasi nonverbal merupakan bagian yang kemungkinan besar dipengaruhi oleh perubahan kondisi fisiologis imdividu, karena umumnya perubahan fisiologis berhubungan dengan perubahan ekspresi mikro individu, seperti perubahan raut wajah, gerakan mata, gerakan alis mata, hingga perubahanperubahan lain di wajah manusia. Keadaan demikian menjadi bagian dari pesan dalam proses komunikasi nonverbal. Sebagaimana kita tahu, bahwa komunikasi nonverbal merupakan bentuk komunikasi yang relatif kaya, bahkan pada beberapa kasus jauh lebih bermakna dibandingkan dengan komunikasi verbal. Menariknya, komunikasi nonverbal cenderung lebih jujur, karena pesan dalam komunikasi tersebut tidak berasal dari keinginan sadar, tapi hadir dari keinginan bawah sadar individu. Karena itu perubahan-perubahan kondisi isi fisiologis manusia, psikologis manusia, dan perubahan mood, memunculkan beragam ekspresi perilaku komunikasi nonverbal yang berbeda.

Peningkatan ketegangan pada pagi hari hingga siang hari, yang dirasakan oleh subyek, memunculkan perubahan perilaku komunikasi nonverbal berubah menjadi lebih tegang, dan mungkin intimidatif terhadap individu lainnya. Pada umumnya perasaan cemas, dan tegang muncul dalam diri subyek pada pagi hari, meskipun data fisiologis berupa tekanan darah dan denyut nadi relatif mengalami penurunan sepanjang tujuh hari, namun tekanan sistol yang realtif tinggi mengindikasikan munculnya ketegangan, meskipun dalam tingkat relatif rendah. Ketegangan tingkat rendah seperti itu umumnya belum terlalu dirasakan oleh subyek, namun perilaku komunikasi nonverbal menunjukkan gejala-gejala ketegangan. Keadaan demikian menguatkan asumsi bahwa tubuh manusia memasuki masa prakondisi ketegangan dan stress, sebelum ketegangan dan stress yang sebenarnya muncul. Prakondisi fisiologis menjadikan perilaku komunikasi nonverbal individu umumnya ikut berubah. Perubahan perilaku komunikasi nonverbal membawa pesan khusus kepada lingkungan sekitar bahwa individu sedang berada dalam kondisi rawan, serta cenderung emosional.

Menariknya, perubahan-perubahan perilaku komunikasi nonverbal seperti itu tidak terjadi setiap hari sepanjang satu pekan, namun terjadi di hari-hari tertentu, khususnya pada hari ketika subyek harus menyelesaikan beragam pekerjaan, seperti mengajar, atau menyelenggarakan kuliah. Di situasi yang lain, khususnya ketika individu tidak menyelesaikan tugas-tugas tertentu, 


\section{Jurnal Komunikasi Nusantara}

\section{E-ISSN. 2685-7650}

Vol. 2 No. 2 (2020), pp 1-19

DOI: https://doi.org/10.33366/jkn.v2i2.46

tingkat ketegangan individu menjadi lebih rendah, sehingga berdampak pada perilaku komunikasi nonverbal individu. Pada kondisi demikian, ekspresi mikro individu menjadi lebih tenang, raut wajah lebih tenang, sorot mata tetap fokus namun lebih tenang, dan perasaan individu menjadi lebih santai. Hal demikian berlangsung hingga siang dan malam hari, terutama jika individu tidak terlalu mendapatkan tekanan dan stress dari pekerjaan. Akan tetapi ketegangan dan kecemasan individu akan bertahan hingga malam hari jika individu mendapatkan pekerjaan relatif berat. Di luar semua itu, kondisi fisiologis individu pada malam hari relatif lebih tenang, karena individu masuk pada tahap pascakondisi stress, yang diindikasikan dengan penurunan tekanan sistol dan penurunan denyut nadi secara bertahap selama tujuh hari, namun demikian ada peningkatan tekanan diastol secara gradual dalam waktu tujuh hari.

Aktivitas fisiologis subyek pada umumnya mengalami penurunan aktivitas pada malam hari, yang notabene juga ditandai dengan penurunan tingkat metabolisme individu. Hal itu berpengaruh besar pada perilaku komunikasi nonverbal, khususnya pada ekspresi mikro dan makro individu. Perubahan ekspresi mikro ditandai dengan sorot mata yang lebih tenang, serta konsentrasi yang lebih rendah, gerakan raut wajah lebih stabil, serta ekspresi-ekspresi lain yang menunjukkan bahwa tingkat stress individu berada pada tingkat paling rendah. Keadaan demikian menurunkan potensi individu berkomunikasi secara agresif, atau menggunakan gestur bermakna mengancam. Kondisi demikian bisa berbeda pada masing-masing individu, tergantung pada tekanan dan tingkat stress yang diterima oleh masing-masing individu. Karena itu perbedaan nilai fisiologis individu yang berbeda, memunculkan potensi perbedaan komunikasi nonverbal untuk masing-masing individu, meskipun di waktu malam.

Perubahan perilaku komunikasi verbal subyek menjadi bagian dari variasi perubahan perilaku komunikasi akibat perubahan kondisi fisiologis individu. Tekanan lingkungan dan stress bisa memasukkan individu dalam kondisi fisiologis yang relatif tidak stabil, sehingga berpengaru pada hampir semua perilaku komunikasi verbal yang dilakukannya. Fluktuasi kadar hormon dalam darah dan reaksi sistem neurologis memicu perubahan konfigurasi dalam otak manusia, yang pada akhirnya bermuara pada perubahan psikologis, dan perubahan emosional yang akhirnya mempengaruhi perilaku komunikasi verbal. Keadaan seperti itu, menjadikan individu cenderung bersifat agresif, dan kasar, yang semuanya bisa diamati dari penggunaan bahasanya. Penggunaan bahasa sejatinya mengindikasikan tiga hal penting. Pertama, agresivitas penggunaan bahasa menunjukkan bahwa individu memiliki kondisi kepribadian yang kurang baik. Hal demikian berkaitan dengan pengendalikan kepribadian oleh otak manusia-di wilayah prefrontal cortex, yang berhubungan dengan unsur-unsur kepribadian individu sebagaimana dijelaskan oleh Sigmund Freud, yaitu id, ego, dan super ego. Kedua, agresivitas bahasa bisa saja muncul ketika individu sedang dalam kondisi stress dan mengalami ketegangan. Kondisi tersebut muncul karena hormon cortisol sedang mempengaruhi sejumlah wilayah di dalam otak manusia, termasuk hippocampus, dan hypothalamus, serta wilayah-wilayah bahasa dan kepribadian di preforntal cortex. Saat itu individu sedang sepenuhnya dikendalikan oleh aspek naluriah, dan meminimalisasi pengendalikan diri dan logika. Ketiga, kombinasi dari kedua kondisi di atas merupakan situasi kritis, yang menjadikan individu kemungkinan besar bisa melakukan beragam tindakan agresif, tidak hanya pada aspek agresivitas bahasa semata, tapi juga tindakan-tindakan 


\section{Jurnal Komunikasi Nusantara}

E-ISSN. 2685-7650

Vol. 2 No. 2 (2020), pp 1-19

DOI: https://doi.org/10.33366/jkn.v2i2.46

berupa agresivitas fisik. Pada konteks ini, penulis hanya memfokuskan pada perubahan perilaku komunikasi menggunakan bahasa verbal, selama pelaksanaan proses WFH.

Perubahan-perubahan perilaku komunikasi verbal dialami oleh individu selama proses WFH, khususnya sering terjadi pada saat pagi hingga siang hari, ketika metabolisme individu dan tingkat stress individu berjalan menuju puncak hingga puncak metabolisme dan stress tercapai di siang hari. Perubahan perilaku komunikasi muncul dengan sejumlah indikasi linguistik umum, yaitu penggunaan kosakata kasar bermakna negatif, dikenal juga sebagai umpatan atau sumpah serapah, atau penggunaan kosakata positif namun dengan intonasi yang lebih tinggi, sebagai tanda bahwa individu sedang mengalami perubahan fisiologis dan psikologis. Ketika individu mengalami tekanan pekerjaan serta mengalami stress, umumnya menggunakan sejumlah kosatakata dan frase tertentu, yang secara khusus digunakan untuk mengintimidasi individu lain, yang bermakna perintah dan semacamnya. Penggunaan bahasabahasa yang bersifat mengintimidasi umumnya berhubungan dengan perubahan kondisi fisiologis dalam diri subyek (perubahan endokrinologis, dan perubahan neurologis). Penggunaan frase-frase yang intimidatif menunjukkan bahwa individu berada dalam kondisi berada dalam ketegangan dan atau stress. Sebagian individu yang lain mungkin mengalami stress yang lebih serius, sehingga memunculkan penggunaan kosakata atau frase yang lebih kasar, berupa umpatan atau sumpah serapah. Perbedaan kondisi masing-masing individu tersebut muncul karena beragam faktor personal dan psikologis, namun di masa pandemik saat ini, semua hal tadi dipicu oleh penyebab yang sama, yaitu aktivitas WFH.

Secara spesifik, perubahan perilaku komunikasi seperti itu tidak terjadi antara individu dengan internet, atau individu lain-yang sedang termediasi menggunakan e-communication, tetapi lebih sering terjadi dengan individu lainnya di lingkungan keluarga. Situasi seperti itu menjadikan individu mungkin akan bersikap lebih keras dan agersif kepada anggota keluarga yang mungkin bisa mengganggu pekerjaan individu. Pada keadaan seperti itu, agresivitas bahasa sesuatu yang mungkin sering terjadi. Agresivitas bahasa seperti itu menunjukkan bahwa individu sedang berada pada posisi tidak menguntungkan, karena sedang di bawah tekanan pekerjaan, ketegangan, dan stress. Menariknya, perilaku komunikasi seperti itu bisa berubah-ubah sesuai dengan keadaan fisiologis dan psikologis individu, serta terjadi secara bertahap pada masingmasing hari.

Pada pagi hari umumnya individu cenderung berkomunikasi secara normal, dengan penggunaan bahasa dengan tensi yang lebih ringan, namun menjelang siang hari intonasi dan tensi berbahasa berubah menjadi lebih tinggi, karena munculnya ketegangan, serta peningkatan kadar hormon tertentu seperti hormon-hormon steroid dan TH. Perubahan tensi dan intonasi berbahasa menurun secara perlahan jika menjelang sore dan malam hari. Situasi demikian kemungkinan besar berhubungan dengan telah terlampauinya ketegangan dan stress di siang hari, sekaligus berkaitan dengan menurunnya tingkat metabolisme individu. Meskipun begitu, perilaku komunikasi akan kembali berubah jika individu mendapatkan permasalahan baru, yang memunculkan ketegangan dan kecemasan. Karena itu, walaupun individu telah berhasil melewati ketegangan pada suatu hari, namun tubuh individu tetap dipersiapkan untuk menghadapi ketegangan pada hari berikutnya, sehingga muncul dinamika yang relatif tinggi pada perilaku komunikasi individu. Pada kondisi yang berbeda, beberapa individu yang lain 


\section{Jurnal Komunikasi Nusantara}

E-ISSN. 2685-7650

Vol. 2 No. 2 (2020), pp 1-19

DOI: https://doi.org/10.33366/jkn.v2i2.46

mungkin akan merasakan kompleksitas perilaku komunikasi dengan memunculkan amarah, kecemasan yang tinggi, dan ketegangan yang makin meningkat, bahkan saat sore hingga malam hari-yang seharusnya terjadi penurunan tingkat metabolisme dan kondisi fisiologis.

Pengendalian diri dan kemampuan individu menghadapi stress merupakan mekanisme efeaktif untuk meminimalisasi agresivitas dalam perilaku komunikasi individu, selama aktivitas WFH. Menariknya, pengendalikan diri dan kemampuan individu melawan stress memiliki tingkat beragam di masing-masing individu, sehingga kemampuan mereka menghadapi tekanan dan situasi juga berbeda. Pada dasarnya, individu memiliki kemampuan dan pilihan untuk melakukan proses komunikasi yang baik atau justru menggunakan komunikasi yang agresif dalam aktivitas sehari-hari. Individu dengan kemampuan pengendalian diri yang baik, serta kepribadian yang baik, umumnya cenderung bisa mengendalikan diri dalam semua kondisi, termasuk dalam kondisi penuh tekanan, seperti yang umum terjadi di masa WFH. Individu semacam itu umumnya masih bisa mengendalikan perilaku komunikasinya, dengan cara tetap menggunakan gaya bahasa yang sopan, baik, tanpa harus berisfat agresif. Meskipun pada umumnya, penekanan pada gaya bahasa, dan intonasi yang digunakan cenderung berbeda, namun ia tetap bisa mengendalikan diri untuk tidak melakukan agresivitas komunikasi, baik secara verbal ataupun nonverbal. Beberapa individu yang lain, mungkin tidak memiliki kemampuan seperti di atas, sehingga stress dan tekanan pekerjaan menjadikan mereka cenderung bertindak agresif dalam semua aspek, khusunya pada perilaku komunikasi yang mereka gunakan. Pada akhirnya, individu yang mampu beradaptasi secara baik —atau setidaknya berusaha maksimal untuk proses adaptasi — dengan gaya hidup baru, yaitu gaya hidup WFH, yang hampir sepenuhnya menggunakan teknologi komunikasi digital untuk menyelesaikan semua pekerjaan.

\section{Kesimpulan}

Analisis dan paparan berdasarkan pengamatan sejumlah data fisiologis (tekanan darah dan denyut nadi) menunjukkan bahwa fluktuasi dan variasi data fisiologis sdi diri subyek selama WFH kemungkinan besar disebabkan oleh ketegangan dan mungkin juga stress selama proses adaptasi dengan gaya hidup WFH. Hal demikian juga berdampak pada munculnya perubahan perilaku komunikasi subyek selama WFH berlangsung. Di samping itu, penggunaan teknologis komunikasi digital (e-communication) selama WFH relatif membutuhkan proses adaptasi yang relatif berat bagi diri subyek. Namun demikian, penulis bisa memperkirakan bahwa perubahan fisiologis subyek selama WFH ialah hasil dari tekanan dan proses adaptasi yang dialami subyek. Lebih detail, perubahan-perubahan nilai fisiologis tersebut menjadi indikasi bahwa individu sedang berada proses adapatasi dalam diri subyek memunculkan kondisi ketegangan dan atau stress, secara lansung bisa mempengaruhi perilaku komunikasi individu. Perubahan perilaku komunikasi individu meliputi perilaku berbahasa dengan lingkungan sekitarnya - khususnya komunikasi dengan anggota keluarga.

Sebagaimana dijelaskan di bagian awal artikel, bahwa artikel ini menjadikan penulis sendiri sebagai obyek penelitian dalam artikel ini, sehingga semua indikasi fisiologis di dalamnya bisa sangat berbeda dengan kondisi pada individu lain, serta perbedaan tekanantekanan yang diterima oleh masing-masing individu. Karena itu penulis menyarankan kepada penulis-penulis lain yang tertarik pada kajian communibiology, khusunya pada tema-tema kaitan 


\section{Jurnal Komunikasi Nusantara}

E-ISSN. 2685-7650

Vol. 2 No. 2 (2020), pp 1-19

DOI: https://doi.org/10.33366/jkn.v2i2.46

antara kondisi fisiologis dengan komunikasi, untuk menambah jumlah informan atau responden yang akan diukur semua indikator fisiologisnya, untuk menambah jumlah variasi data fisiologis, sehingga muncul pola-pola fisiologis yang lebih kaya dan lebih obyektif. Meskipun penulis bisa memperkirakan bahwa perubahan nilai fisiologis selama WFH kemungkinan besar berkaitan dengan ketegangan dan stress, selama proses adaptasi, namun penulis tetap menyarankan menggunakan peralatan yang lebih canggih untuk mengukur indicator-indikator fisiologis yang lebih kompleks, seperti misalnya penggunaan heart-rate monitor (ECG) dan electroencephalograph (EEG). Dengan demikian penggunaan peralatan yang lebih canggih diharapkan bisa memberikan informasi data fisiologis secara lebih baik, sehingga penulis bisa membangun pemahaman dan interpertasi yang lebih baik pula, tentang ketegangan dan stress dalam kaitannya dengan tekanan pekerjaan dan atau rutinitas harian individu. Di samping itu, peningkatan jumlah informan atau responden, penulis bisa mendapatkan variasi data yang lebih luas pada aspek perilaku komunikasi di antara masing-masing informan atau responden. Pada akhirnya penulis-penulis selanjutnya bisa memberikan pemahaman yang lebih baik tentang kaitan antara tekanan lingkungan dengan perubahan kondisi fisiologis, dan perilaku komunikasi.

\section{Ucapan Terima Kasih}

Peneliti mengucapkan banyak terima kasih kepada Dr. Antoni, yang telah meluangkan waktu untuk memberikan saran, koreksi, dan masukkan keilmuan bagi perbaikan penulisan artikel ini. Selain itu, Dr. Antoni menjadi sosok yang memiliki ketertarikan kepada topik kajian communibiology, sama seperti ketertarikan penulis terhadap kajian tersebut. Karena itu, penulis berharap bahwa artikel jurnal ini bisa bermanfaat bagi komunitas akademis, dan masyarakat luas.

\section{Daftar Pustaka}

Antoni, H. (1996). The Cardiac Function Cycle. dalam R. Greger dan U. Windhorst (editor). Comprehensive Human Physiology, From Cellular Mechanism to Integration. 1793-1799. Berlin: Springer.

Beatty, M. J. (2008). Communibiology. dalam Wolfgang Donsbach (editor) The International Encyclopedia of Communication. 585-591. Malden: Blackwell Publishing.

Caughlin, J. P. Scott, A. M. (2008). Family Communication Pattern. dalam Wolfgang Donsbach (editor) The International Encyclopedia of Communication.1723-1729. Malden: Blackwell Publishing.

Coste, S. Murray, S. E. Stenzel-Poore, M. P. (2005). Gene targeted animals with alteration in cortocotropin pathways: new insight in allostatic control. dalam T. Steckler, N. H. Kalin, J. M. H. M. Reul (editor). Handbook of Stress and the Brain, part 2 Stress: Integrative and clinical aspect, vol 15. 51-74 .Amsterdam: Elsevier.

Dougall, A. L. Baum, A. (2003). Stress, Coping, and Immune Function. dalam Michela Gallagher dan Randy J. Nelson (editor) Handbook of Psychology, Volume 3, Biological Psychology. 441-455. New Jersey: John Wiley \& Sons, Inc.

Ellenbroek, B. A. Geven, E. J. Cools, A. R. (2005). Rat strain differences in stress activity. dalam T. Steckler, N. H. Kalin, J. M. H. M. Reul (editor). Handbook of Stress and the Brain, part 2 Stress: Integrative and clinical aspect, vol 15. 75-87. Amsterdam: Elsevier. 


\section{Jurnal Komunikasi Nusantara}

E-ISSN. 2685-7650

Vol. 2 No. 2 (2020), pp 1-19

DOI: https://doi.org/10.33366/jkn.v2i2.46

Fajar, D. P (2015). Kajian Tentang Literasi Media Massa Berdasarkan Perspektif Biologi Komunikasi. dalam Jurnal Komunikasi Massa. Vol 8, No 1: 47-58.

Fox, S. E. (1996). The Function of Limbic System. dalam R. Greger dan U. Windhorst (editor). Comprehensive Human Physiology, From Cellular Mechanism to Integration. 355-378. Berlin: Springer.

Greger, R. Bleich, M. (1996). Normal Values for Physiological Parameters. dalam R. Greger dan U. Windhorst (editor). Comprehensive Human Physiology, From Cellular Mechanism to Integration. 2427-2449. Berlin: Springer.

Hole, J. W. (1993). Human Anatomy \& Physiology. sixth edition. Dubuque: Wm. C Brown Publisher

Jacobson, T. (2008). Participatory Action Research. dalam Wolfgang Donsbach (editor) International Encyclopedia of Communication: 3511-3517. Malden: Blackwell Publishing.

Jordan, S. (2008). Participatory Action Research (PAR). dalam Lisa M. Given (editor) The SAGE Encyclopedia of Qualitative Research Methods. vol 1-2. 601- 604. Thousand Oaks: SAGE Publication.

Koizumi, K. (1996) The Role of Hypothalamus in Neuroendocrinology. dalam R. Greger dan U. Windhorst (editor). Comprehensive Human Physiology, From Cellular Mechanism to Integration. 379-402. Berlin: Springer.

McEwen, B. S. (1996). Hormones Modulate Enviromental Control of a Changing Brain. dalam R. Greger dan U. Windhorst (editor). Comprehensive Human Physiology, From Cellular Mechanism to Integration. 470-493. Berlin: Springer.

Pryce, C. R, et al (2005). Early life environmental manipulation im rodents and primates: Potentian animal model in depression research. dalam T. Steckler, N. H. Kalin, J. M. H. M. Reul (editor). Handbook of Stress and the Brain, part 2 Stress: Integrative and clinical aspect, vol 15. 23-51 .Amsterdam: Elsevier.

Sharkey, K. A. Pittman, Q. J. (1996). The Autonomic Nevous System: Peripheral and Central Integrative Aspects: dalam R. Greger dan U. Windhorst (editor). Comprehensive Human Physiology, From Cellular Mechanism to Integration. 335-353. Berlin: Springer.

Tonacci, A. et al. (2019). Exhaled breath analysis in evaluation of psychological stress: A short literature review. dalam International Journal of Psychology. Vol 54, No 5: 589-597

Tortora, G. J. Derrickson, B. (2011). Principles of Anatomy \& Physiology. (13th edition). vol 1. New Jersey: John Wiley \& Sons.

Villee, C. A. Walker, W. F, Barnes, R. D. (1999). Zoologi Umum, (edisi keenam), Nawangsari Sugiri (penerjemah), cetakan kedua. Jakarta: Erlangga.

Windhorst, U. (1996). Regulatory Principles in Physiology. dalam R. Greger dan U. Windhorst (editor). Comprehensive Human Physiology, From Cellular Mechanism to Integration. 2142. Berlin: Springer. 